\title{
Appropriate Concentration of Acetic Acid for the Preservation of Fresh Cadaveric Brains to be Used in Surgical Training: A Preliminary Study
}

\author{
Concentración Adecuada de Ácido Acético para la Preservación de Cerebros de \\ Cadáveres Frescos para Uso en Entrenamiento Quirúrgico: Un Estudio Preliminar
}

Nontaphon Piyawattanametha'; Intouch Sopchokchai'; Kowit Chaisiwamongkol'; Nawiya Kitkhuandee ${ }^{3}$ Punnarat Sirataranon ${ }^{1}$; \& Sitthichai Iamsaard ${ }^{2,4}$

PIYAWATTANAMETHA, N.; SOPCHOKCHAI, I.; CHAISIWAMONGKOL, K.; KITKHUANDEE, N.; SIRATARANON, P. \& IAMSAARD, S. Appropriate concentration of acetic acid for the preservation of fresh cadaveric brains to be used in surgical training: A preliminary study. Int.J. Morphol., 37(3):1107-1110, 2019.

SUMMARY: A small amount of acetic acid (AA), a common preservative, has been shown to increase contamination in cadaveric tissue, while larger concentrations can lead to the tissue becoming hard, especially in fresh brains. This study attempted to optimize the concentration of AA to be used in the cranial cavity in order to produce the most realistic consistency and color. Six adult cadaveric heads were preserved with descending glacial AA at concentrations of $98.5 \%, 80 \%, 60 \%, 40 \%, 20 \%$, and $10 \%$. The samples were kept at $5{ }^{\circ} \mathrm{C}$ for 14 days. The brain cortex was then dissected with a suction tube and forceps to reveal the underlying brain tissue for inspection. Color change, cortical firmness, pia mater stickiness, and participant satisfaction were evaluated. The color of the brains in all concentrations was slightly yellow. However, the temporal area of the brain preserved using $20 \%$ AA was significantly more pink. The pia mater of the brain cortex of all samples was firm and difficult to pry apart, with the firmest consistency being in the brain tissue preserved using 98.5\% AA. The brain tissue in all samples had a liquid-like consistency. The brains preserved in AA at a concentration greater than $60 \%$ yielded higher satisfaction scores. We conclude that acetic acid has a role in brain preservation for skull base surgery training and recommend AA concentrations higher than $60 \%$ for maximal participants satisfaction.

KEY WORDS: Acetic acid; Concentration; Preservation; Fresh cadaver; Brain.

\section{INTRODUCTION}

Acetic acid (AA) is a preservative commonly used to prevent bacterial and fungal growth in wound dressings and in the food industry (Febriana et al., 2012; Shukla et $a l ., 2017)$. It has been used in post-mortem cadavers to preserve the skin color, softness, and joint mobility for fresh cadaveric surgery demonstrations (Brenner, 2014; Varlet et al., 2018). However, using a small amount of AA has been shown to increase contaminations in cadaveric tissue (Trcek et al., 2015), while larger concentrations can lead to the tissue becoming hard, especially in fresh brains.

A tremendous amount of skill and attention to detail is required to adequately address the risks that accompany surgery performed on the nervous system, which means that rigorous training is necessary before a resident can become a competent neurosurgeon. Neurosurgery residency training in Thailand takes at least of 5 years to complete. The Royal College of Surgeons of Thailand (2018) recently declared that certain milestones must be reached before this training is complete, with the ability to perform a number of specific procedures being one of them. One of the many strengths of Khon Kaen University (KKU) neurosurgery residency program is the availability of cadavers, which are donated by local residents through the Department of Anatomy. The Neurosurgery Division of the Faculty of Surgery has been organizing triennial conferences with live instruction and hands-on experience using the heads of these cadavers for the past 5 years for interested residents and neurosurgeons from all over the country. Some of the benefits of practicing on cadavers include the opportunity to familiarize oneself

\footnotetext{
${ }^{1}$ Neurosurgery Division, Department of Surgery, Khon Kaen University, Khon Kaen Province 40002, Thailand.

${ }^{2}$ Department of Anatomy, Khon Kaen University, Khon Kaen Province 40002, Thailand.

${ }^{3}$ Demonstration School of Khon Kaen University, Khon Kaen Province 40002, Thailand.

${ }^{4}$ Center for Research and Development of Herbal Health Product, Faculty of Pharmaceutical Sciences, Khon Kaen University, Khon Kaen Province 40002, Thailand.
} 
PIYAWATTANAMETHA, N.; SOPCHOKCHAI, I.; CHAISIWAMONGKOL, K.; KITKHUANDEE, N.; SIRATARANON, P. \& IAMSAARD, S. Appropriate concentration of acetic acid for the preservation of fresh cadaveric brains to be used in surgical training: A preliminary study. Int. J. Morphol., 37(3):1107-1110, 2019.

with surgical tools, the ability to become used to the configurations of the cranial vasculature, as well as the chance to feel more comfortable and confident navigating through the complicated skull base. However, there are still problems encountered with using the cadaveric brains that should be addressed. A fixative solution consisting of a mix of glycerin and formalin is routinely used for cadaver preservation at KKU. However, the glycerin makes the brain overly pulpy, rendering the samples impossible to dissect. When preserved with formalin, the brains become hard and inelastic, characteristics unsuitable for dissection. In addition to its distinct, pungent smell and color-altering properties, formalin has been classified as an occupational hazard for health personnel. It has been reported to cause contact dermatitis, upper airway inflammation, asthma, and is implicated in nasopharyngeal cancer, sinonasal cancer, and lymphohematopoietic cancer (Nelson et al., 1986; Raja \& Sultana, 2012; Friis et al., 2014; Pontén \& Bruze, 2015; Davies, 2016; Kim et al., 2016). Over the past 100 years, various substances have been reported as being used preservation of the cadaveric tissue. The method of preservation mostly involves bathing the whole cadaver in a certain solution, with an unquantifiable portion of said solution entering the brain. Such solutions include fomepizole, phenoxyethanol, formaldehyde, formalin, and diethylene glycol, each of which have several advantages and disadvantages (Brenner).

Acetic acid's use in the preservation of the postmortem cadaver has been documented as early as in the 19th century by French chemist Jean-Nicholas Gannal (Brenner). In particular, glacial acetic acid has been shown to preserve skin color, skin softness, and joint mobility in the cadaveric arm (Tschernezky, 1984). The aim of this study was to investigate the optimal concentration of acetic acid to be poured into the cadaver's cranial cavity in order to give fresh cadaveric brain tissue the most realistic consistency and color.

\section{MATERIAL AND METHOD}

Six fresh cadaveric heads were obtained from the KKU body donation program, in accordance with the standard procedures of the Khon Kaen University Faculty of Medicine's Department of Anatomy. All of the cadaveric heads were of adults aged more than 18 years and deceased not longer than 3 days, and were stored in a cool preserving chamber. There were no exclusion criteria. Since this was a pilot study, there were yet no standards as to the optimum number of samples. A Burr hole was made at the vertex position in each cadaveric head. The heads were then placed upside down in a $5{ }^{\circ} \mathrm{C}$ refrigerator in order to drain all residual fluids. After $48 \mathrm{~h}$, industrial grade $98.5 \%$ glacial acetic acid was diluted with tap water to $80 \%, 60 \%$, $40 \%, 20 \%$, and $10 \%$ concentrations, and each solution (including one that was undiluted) was poured into a separate head until full. The heads were then placed upright and stored in a $5{ }^{\circ} \mathrm{C}$ refrigerator. After another 48 hours, the level of the acetic acid at the Burr hole was examined, as it tends to decrease, presumably because it flows into and fills up smaller spaces in the skull cavity. Acetic acid at the same concentration was then added fill the head up to the Burr hole entrance. The cadaveric heads were then left in the $5{ }^{\circ} \mathrm{C}$ refrigerator for another 14 days. A traumatic flap was used to access the brain tissue, which was then examined for color and pia mater firmness by ten participants including neurosurgical residents and neurosurgeons. The brain cortex was then dissected with a suction tube and forceps to reveal the underlying brain tissue for inspection. Color, cortical firmness (on a scale of 1-5: 5 = very hard, $4=$ fairly hard, $3=$ firm, $2=$ fairly soft, $1=$ very soft), pial stickiness, and participant satisfaction (on a scale of 1-5: $1=$ Not at All Satisfied, $2=$ Partly Satisfied, 3= Satisfied, 4 = More than Satisfied, 5 =Very Satisfied) were evaluated.

\section{RESULTS}

The summary of our findings is shown in Table I. The color of all of the brains was more or less retained, appearing only slightly yellower. The brain that received 20 $\%$ acetic acid had a subarachnoid hemorrhage, with the temporal area appearing significantly more pink. All participants agreed that the pial mater of the brain cortex of all samples was firmed and difficult to pry apart. The cadaveric head preserved with $98.5 \%$ acetic had the firmest consistency, with firmness decreasing with the acid concentration (Table I). In addition, it was observed that firmness was not distributed equally in the brains preserved with concentrations lower than $60 \%$ (Table I). Apart from the brain preserved with $40 \%$ solution, all specimens felt firmer near the temporal area. After the pia mater was separated with a scalpel, the brain tissue in all samples was observed to have a liquid-like consistency.

\section{DISCUSSION}

Acetic acid has been used for preservation of the post-mortem cadavers early as in the $19^{\text {th }}$ century (Brenner). However, this study was the first to preliminarily 
PIYAWATTANAMETHA, N.; SOPCHOKCHAI, I.; CHAISIWAMONGKOL, K.; KITKHUANDEE, N.; SIRATARANON, P. \& IAMSAARD, S. Appropriate concentration of acetic acid for the preservation of fresh cadaveric brains to be used in surgical training: A preliminary study. Int. J. Morphol., 37(3):1107-1110, 2019.

Table I. Summary of acetic acid concentrations with satisfaction parameters.

\begin{tabular}{|c|c|c|c|c|c|c|}
\hline Cadaveric heads $(\mathrm{H})$ & $\mathrm{H} 1$ & $\mathrm{H} 2$ & $\mathrm{H} 3$ & $\mathrm{H} 4$ & H5 & H6 \\
\hline Acetic acid concentration ( $\%)$ & $98.5 \%$ & $80 \%$ & $60 \%$ & $40 \%$ & $20 \%$ & $10 \%$ \\
\hline Initial acetic acid poured (ml) & 130 & 90 & 100 & 110 & 50 & 160 \\
\hline Additional acetic acid at $48 \mathrm{hr}(\mathrm{ml})$ & 130 & 120 & 125 & 130 & 80 & 200 \\
\hline Color at 14 days & $\begin{array}{l}\text { Slightly } \\
\text { yellow }\end{array}$ & $\begin{array}{l}\text { Slightly } \\
\text { yellow }\end{array}$ & $\begin{array}{l}\text { Slightly } \\
\text { yellow }\end{array}$ & $\begin{array}{l}\text { Slightly } \\
\text { yellow }\end{array}$ & $\begin{array}{l}\text { Slightly yellow, } \\
\text { pink at temporal } \\
\text { lobe }\end{array}$ & $\begin{array}{l}\text { Slightly } \\
\text { yellow }\end{array}$ \\
\hline F irmness at 14 days (Scales: $1-5$ ) & 3 & 3 & 3 & 3 & 2 & 1 \\
\hline P ia mater stickiness & Sticky & Sticky & Sticky & Sticky & Sticky & Sticky \\
\hline Additional notes & NA & NA & NA & NA & $\begin{array}{l}\text { Sylvian } \\
\text { subarachnoid } \\
\text { hemorrhage }\end{array}$ & $\mathrm{NA}$ \\
\hline P articipant satisfaction (Scales: $1-5$ ) & 5 & 5 & 4 & 3 & 2 & 1 \\
\hline
\end{tabular}

Note: Cortical firmness ( 5 = Very hard, $4=$ fairly hard, $3=$ Firm, $2=$ fairly soft, $1=$ Very soft $)$. Participant satisfactions $(1=$ Not at All Satisfied, 2 = Partly Satisfied, 3= Satisfied, 4 = More than Satisfied, 5 =Very Satisfied).

demonstrate the preservative properties and optimal concentrations of acetic acid in fresh human brain tissue for use in skull base surgery training. Although similar properties have been reported in skin and joint preservation (Brenner; Varlet et al.), this study showed that it could also be used to preserve fresh whole brains. There is the possibility that this cheap and accessible solution could be superior to the solutions currently being used as a brain preservation liquid, with all 10 blinded trainees and attending physicians indicating their satisfaction with the results. One weakness of this study was its small sample size. In addition, the fact that one of the brains had a subarachnoid hemorrhage might have affected the amount of acetic acid that was used, compromising the results. Most of the brains tended to have a slightly firmer consistency near the temporal area, presumably due to the pooling of acetic acid on the tentorium cerebelli. However, brains preserved in acetic acid at concentrations of $60 \%$ or higher received higher satisfaction scores, which suggests that acetic acid could have a role in brain preservation for the purpose of skull base surgery training. Further studies with larger samples and tighter control on intracranial pathologies will be performed. In conclusion, acetic acid is shown to be a viable choice for the preservation of brain tissue for the purpose of cadaveric study. The tissue exhibited a desirable amount of firmness and intact color. We recommend using $60 \%$ acetic concentration and above for maximal satisfaction.

\section{ACKNOWLEDGEMENTS}

We would like to thank the Khon Kaen University Faculty of Medicine Department of Anatomy for providing the valuable cadaveric heads, which were donated by local residents.
PIYAWATTANAMETHA, N.; SOPCHOKCHAI, I.; CHAISIWAMONGKOL, K.; KITKHUANDEE, N.; SIRATARANON,P. \& IAMSAARD, S. Concentración adecuada de ácido acético para la preservación de cerebros de cadáveres frescos para uso en entrenamiento quirúrgico: un estudio preliminar. Int. J. Morphol., 37(3):1107-1110, 2019.

RESUMEN: Se ha demostrado que una pequeña cantidad de ácido acético (AA), un preservante común, aumenta la contaminación en el tejido del cadáver, mientras que mayores concentraciones pueden endurecer el tejido, particularmente en cerebros frescos. Este estudio intentó optimizar la concentración de AA en la cavidad craneal para producir una consistencia y coloración cerebral más cercanos a la realidad. Seis cabezas cadavéricas adultas se conservaron con AA glacial descendente en concentraciones de $98,5 \%, 80 \%, 60 \%, 40 \%, 20$ $\%$ y $10 \%$. Las muestras se mantuvieron a $5{ }^{\circ} \mathrm{C}$ durante 14 días. Luego se diseccó la corteza cerebral con un tubo de succión y pinzas para observar e inspeccionar el tejido cerebral subyacente. Se evaluaron el color, la firmeza cortical, la viscosidad y adherencia de la piamadre y la reacción de los participantes ante esta conservación. El color de los cerebros en todas las concentraciones fue ligeramente amarillo. Sin embargo, el área temporal del cerebro, conservada con un $20 \%$ de AA, fue significativamente más rosada. La piamadre de la corteza de todas las muestras fue de consistencia firme y difícil de separar; una mayor resistencia se observó en el tejido cerebral preservado con 98,5\% de AA. La consistencia del tejido cerebral en todas las muestras era líquida. Los cerebros conservados en AA a una concentración superior al $60 \%$ recibieron puntuaciones de satisfacción más elevadas. Concluimos que el ácido acético desempeña un papel en la preservación del cerebro, permitiendo el entrenamiento en cirugía de base de cráneo, por lo que recomendamos concentraciones de AA superiores al $60 \%$ para una satisfacción máxima por parte de los participantes.

PALABRAS CLAVE: Ácido acético; Concentración; Conservación; Cerebro; Cadáver fresco. 
PIYAWATTANAMETHA, N.; SOPCHOKCHAI, I.; CHAISIWAMONGKOL, K.; KITKHUANDEE, N.; SIRATARANON, P. \& IAMSAARD, S. Appropriate concentration of acetic acid for the preservation of fresh cadaveric brains to be used in surgical training: A preliminary study. Int. J. Morphol., 37(3):1107-1110, 2019.

\section{REFERENCES}

Brenner, E. Human body preservation - old and new techniques. J. Anat., 224(3):316-44, 2014.

Davies, T. Health problems have come in wake of contact with chemicals. Nurs. Stand., 30(39):30-1, 2016.

Febriana, S. A.; Jungbauer, F.; Soebono, H. \& Coenraads, P. J. Inventory of the chemicals and the exposure of the workers' skin to these at two leather factories in Indonesia. Int. Arch. Occup. Environ. Health, 85(5):517-26, 2012.

Friis, U. F.; Dahlin, J.; Bruze, M.; Menné, T. \& Johansen, J. D. Hidden exposure to formaldehyde in a swab caused allergic contact dermatitis. Contact Dermatitis, 70(4):258-60, 2014.

Kim, J.; Han, Y.; Ahn, J. H.; Kim, S. W.; Lee, S. I.; Lee, K. H. \& Ahn, K. Airborne formaldehyde causes skin barrier dysfunction in atopic dermatitis. Br. J. Dermatol., 175(2):357-63, 2016.

Nelson, N.; Levine, R. J.; Albert, R. E.; Blair, A. E.; Griesemer, R. A.; Landrigan, P. J.; Stayner, L. T. \& Swenberg, J. A. Contribution of formaldehyde to respiratory cancer. Environ. Health Perspect., 70:2335,1986 .

Pontén, A. \& Bruze, M. Formaldehyde. Dermatitis, 26(1):3-6, 2015.

Raja, D. S. \& Sultana, B. Potential health hazards for students exposed to formaldehyde in the gross anatomy laboratory. J. Environ. Health, 74(6):36-40, 2012.

Royal College of Surgeons of Thailand. Neurosurgery residency training program. Bangkok, Royal College of Surgeons of Thailand, 2018. Available from: http://www.rcst.or.th/th/training-courses/ view.php?_did=34

Shukla, P.; Akshay, S. \& Ashok, S. Food additives from an organic chemistry perspective. M. O. J. Biorgan. Org. Chem., 1(3):70-9, 2017.

Trček, J.; Mira, N. P. \& Jarboe, L. R. Adaptation and tolerance of bacteria against acetic acid. Appl. Microbiol.Biotechnol., 99(15):6215-29, 2015.

Tschernezky, W. Restoration of the softness and flexibility of cadavers preserved in formalin. Acta Anat. (Basel), 118(3):159-63, 1984.

Varlet, V.; Ryser, E.; Augsburger, M.\& Palmiere, C. Stability of postmortem methemoglobin: Artifactual changes caused by storage conditions. Forensic Sci. Int., 283:21-8, 2018.
Corresponding author:

Assoc. Prof. Sitthichai lamsaard

Department of Anatomy

Khon Kaen University

Khon Kaen Province 40002

THAILAND

\section{Email: sittia@kku.ac.th}

Received: 31-01-2019

Accepted: 30-04-2019 